\title{
Phosphorylation of c-Jun Is Necessary for Apoptosis Induced by Survival Signal Withdrawal in Cerebellar Granule Neurons
}

\author{
Andrea Watson, ${ }^{1}$ Andreas Eilers, ${ }^{1}$ Dominique Lallemand, ${ }^{2}$ John Kyriakis, ${ }^{3}$ Lee L. Rubin, ${ }^{4}$ and Jonathan Ham ${ }^{1}$ \\ ${ }^{1}$ Eisai London Research Laboratories, University College London, London WC1E 6BT, United Kingdom, ${ }^{2}$ Unité des Virus \\ Oncogènes, Département des Biotechnologies, Institut Pasteur, 75724 Paris Cedex 15, France, ${ }^{3}$ Diabetes Unit, \\ Massachusetts General Hospital, Charlestown, Massachusetts 02129, and ${ }^{4}$ Ontogeny, Inc., \\ Cambridge, Massachusetts 02139
}

\begin{abstract}
Cerebellar granule neurons die by apoptosis when deprived of survival signals. This death can be blocked by inhibitors of transcription or protein synthesis, suggesting that new gene expression is required. Here we show that $c-j u n$ mRNA and protein levels increase rapidly after survival signal withdrawal and that transfection of the neurons with an expression vector for a c-Jun dominant negative mutant protects them against apoptosis. Phosphorylation of serines 63 and 73 in the c-Jun transactivation domain is known to increase c-Jun activity. By using an antibody specific for C-Jun phosphorylated on serine 63 , we show that this site is phosphorylated soon after survival signal withdrawal. To determine whether c-Jun phosphorylation is necessary for apoptosis, we have expressed c-Jun phosphorylation site mutants in granule neurons. c-Jun asp, a constitutively active c-Jun mutant in which the known and potential
\end{abstract}

During the development of the mammalian nervous system approximately half of the neurons that are formed subsequently die by apoptosis (Oppenheim, 1991). This death is usually the result of the limited availability of specific neurotrophic factors, which are required for the survival of developing neurons, and is thought to be a mechanism for ensuring that neuronal targets are innervated by the correct density of neurons (Barde, 1989). In the case of several different types of primary neuron cultured in vitro, inhibitors of transcription or protein synthesis block cell death caused by survival factor withdrawal (Martin et al., 1988; Scott and Davies, 1990; D'Mello et al., 1993; Milligan et al., 1994), suggesting that survival signal removal may activate genes whose products promote cell death (Johnson and Deckwerth, 1993). Initial studies of the transcriptional control of cell death in nerve growth factor (NGF)-dependent sympathetic neurons demonstrated that the transcription factor c-Jun plays a key role. Inhibition of the function of c-Jun, either by microinjection of antibodies against c-Jun or by expression of a c-Jun dominant negative mutant, protected sympathetic neurons from NGF withdrawal-induced death (Estus et al., 1994; Ham et al., 1995).

\footnotetext{
Received April 9, 1997; revised Oct. 1, 1997; accepted Nov. 5, 1997.

This work was financed by the Eisai Company of Japan. We thank Chantal Bazenet, Alan Hall, and Moshe Yaniv for useful discussions and critical reading of this manuscript and Joanne Taylor for advice on the preparation of cerebellar granule neurons. We are also grateful to Dr. Angel Nebreda for providing the mpk2/p38 antibody and to Dr. Dirk Bohmann for the expression vectors for c-Jun, c-Jun ala, and c-Jun asp.

Correspondence should be addressed to Jonathan Ham, Eisai London Research Laboratories, Bernard Katz Building, University College London, Gower Street, London WC1E 6BT, UK.

Copyright (C) 1998 Society for Neuroscience $\quad 0270-6474 / 98 / 180751-12 \$ 05.00 / 0$
}

serine and threonine phosphoacceptor sites in the transactivation domain have been mutated to aspartic acid, induces apoptosis under all conditions tested. In contrast, c-Jun ${ }^{\text {ala }}$, which cannot be phosphorylated because the same sites have been mutated to alanine, blocks apoptosis caused by survival signal withdrawal. Finally, we show that cerebellar granule neurons contain high levels of Jun kinase activity and low levels of p38 kinase activity, neither of which increases after survival signal withdrawal. Mitogen-activated protein kinase activity decreases under the same conditions. These results suggest that c-Jun levels and c-Jun phosphorylation may be regulated by novel mechanisms in cerebellar granule neurons.

Key words: AP-1; apoptosis; cerebellar granule neurons; cJun; Jun kinase; signal transduction; stress-activated protein kinases

In the present study, we have investigated whether c-Jun is necessary for apoptosis in cerebellar granule neurons. When isolated from 8-d-old rats, cerebellar granule neurons can be maintained in vitro by adding $10 \%$ serum and $25 \mathrm{~mm} \mathrm{KCl}$ to the culture medium (D'Mello et al., 1993). If, after $7 \mathrm{~d}$ in vitro, the serum is removed, and the $\mathrm{KCl}$ concentration is reduced from 25 to $5 \mathrm{~mm}$, the granule neurons die by apoptosis, and this death is transcription-dependent (D'Mello et al., 1993). Miller and Johnson (1996) reported that the level of c-jun RNA increases in cerebellar granule neurons after $\mathrm{KCl}$ and serum deprivation but did not investigate whether the activity of c-Jun was required for cell death. Here we show that after survival signal withdrawal, $c$-jun RNA and protein levels increase before the transcriptional commitment point and that apoptosis can be inhibited by expressing a c-Jun dominant negative mutant. The transcriptional activity of c-Jun is increased by phosphorylation of serines 63 and 73 in the transactivation domain (Pulverer et al., 1991; Smeal et al., 1991). Using a phospho-c-Jun-specific antibody, we demonstrate that c-Jun is phosphorylated on serine 63 during apoptosis, and, by expressing c-Jun mutants in which specific phosphorylation sites have been altered, we show that phosphorylation of c-Jun is necessary for apoptosis to occur after survival signal withdrawal. Finally, we have measured the activity in granule neuron extracts of Jun amino terminal kinases (JNKs), also known as stress-activated protein kinases (SAPKs), which phosphorylate serines 63 and 73 in c-Jun (Dérijard et al., 1994; Kyriakis et al., 1994), and the activities of p38 kinase and mitogen-activated protein (MAP) kinase. The results of these 
assays suggest that in cerebellar granule neurons c-Jun protein levels and c-Jun phosphorylation may be regulated by novel mechanisms.

\section{MATERIALS AND METHODS}

Cell culture. Cerebellar granule neurons were isolated from the cerebella of 8-d-old Sprague Dawley rats (supplied by the Biological Services Unit, University College London) as described by Taylor et al. (1997). The neurons were separated from non-neuronal cells by centrifugation at $1200 \times g$ for 20 min through $40.5 \%$ Percoll (Sigma, Poole, UK) and were plated in basal medium Eagle (BME; Life Technologies, Paisley, UK) supplemented with $10 \%$ fetal calf serum (Globepharm, Esher, UK), 25 $\mathrm{mM} \mathrm{KCl,} 35 \mathrm{mM}$ glucose, and penicillin/streptomycin on polyornithinecoated dishes or glass coverslips. Cells were plated at a density of $5.6 \times$ $10^{5} / \mathrm{cm}^{2}$. Approximately $24 \mathrm{hr}$ after plating, cytosine arabinofuranoside (Sigma) was added to the culture medium to a final concentration of 10 $\mu \mathrm{M}$ to prevent the proliferation of any non-neuronal cells. Using this protocol 95-99\% of the cultured cells were neurons (Hatten, 1985; Gao et al., 1991). Apoptosis was induced by reducing the extracellular potassium concentration from 25 to $5 \mathrm{~mm}$ as follows. Cells that had been cultured for 6-7 d in vitro were rinsed three times in serum-free BME containing $5 \mathrm{~mm} \mathrm{KCl}$ supplemented with glucose and penicillin/streptomycin and then were maintained in the same medium. Control cultures were treated identically but were maintained in serum-free medium supplemented with $\mathrm{KCl}$ at $25 \mathrm{~mm}$. Neuronal survival was assessed by MTT (Sigma) conversion to formazan by live cells (Mosmann, 1983) or, on the basis of nuclear morphology, visualized by staining paraformaldehyde-fixed cells with Hoechst dye (H33342, CalbiochemNovabiochem UK Ltd.).

PC12 cells were cultured in a defined medium supplemented with $2 \%$ fetal calf serum and $10 \mu \mathrm{g} / \mathrm{ml}$ insulin as described by Ham et al. (1995). HeLa and Rat1 cells were cultured in DMEM (Life Technologies) with $10 \%$ FCS. For treatment with UV radiation, HeLa cells were grown to confluence and then left in DMEM with $0.5 \%$ FCS overnight. The cells were exposed to short-wavelength UV radiation $(254 \mathrm{~nm})$ for $1 \mathrm{~min}$ using a hand-held UV lamp and were harvested 30 min later. Subconfluent Rat1 cells were treated in a similar manner.

Immunoblotting. Whole cell extracts were prepared from cultured cerebellar granule neurons by lysing cells in SDS buffer containing $1 \mathrm{~mm}$ PMSF, $1 \mu \mathrm{g} / \mathrm{ml}$ pepstatin A, $5 \mu \mathrm{g} / \mathrm{ml}$ leupeptin, and $2 \mu \mathrm{g} / \mathrm{ml}$ aprotinin, as described by Ham et al. (1995). The resulting lysate was then cleared by centrifugation. Proteins were separated on $12.5 \%$ SDS polyacrylamide gels. Fifteen micrograms of extract were loaded per lane. After electrophoresis, the separated proteins were electroblotted onto Hibond ECL nitrocellulose (Amersham, Little Chalfont, UK). Jun and Fos family members were detected with affinity-purified rabbit polyclonal antibodies as described previously (Ham et al., 1995; Lallemand et al., 1997) using a horseradish peroxidase-conjugated anti-rabbit secondary antibody and the ECL system (Amersham). Relative levels of protein were determined by scanning autoradiographs on an imaging densitometer (Bio-Rad).

In vitro-translated c-Jun phosphorylated on serine 63 was detected with an affinity-purified rabbit polyclonal phospho-c-Jun antibody that was raised against a peptide corresponding to mouse c-Jun amino acids 57-68 with a phosphorylated serine at position 63 (D. Lallemand, unpublished observations). To detect c-Jun phosphorylated on serine 63 in extracts prepared from cerebellar granule neurons, a sequential immunoprecipitation and immunoblotting experiment was performed. For these experiments, cells were lysed in high-salt lysis buffer (50 mM HEPES, pH 7.0, $500 \mathrm{mM} \mathrm{NaCl}$, and 1\% NP-40) supplemented with PMSF, leupeptin, aprotinin, $10 \mathrm{~mm} \mathrm{NaF}$, and $100 \mu \mathrm{M} \mathrm{Na}$ orthovanadate. After incubation on ice for $20 \mathrm{~min}$, the cell extract was centrifuged at $13,000 \times \mathrm{g}$ for $5 \mathrm{~min}$, and the supernatant was transferred to a fresh tube and stored at $-80^{\circ} \mathrm{C}$. For immunoprecipitations, protein A-agarose beads (Boehringer Mannheim) were washed three times in NET buffer (50 mM Tris, pH 7.5, 150 $\mathrm{mm} \mathrm{NaCl}, 0.1 \% \mathrm{NP}-40$, and 1 mM EDTA). Three hundred micrograms of cell extract were then made up to a final volume of $700 \mu \mathrm{l}$ and a final $\mathrm{NaCl}$ concentration of $150 \mathrm{~mm}$ using $\mathrm{NET}$ buffer with no $\mathrm{NaCl}$. Fifty microliters of washed protein A beads were then added, and the tube was rotated for $1 \mathrm{hr}$ at $4^{\circ} \mathrm{C}$. The beads were then spun down, and the supernatant was transferred to a fresh tube. Phospho-c-Jun polyclonal antibody $(1.5 \mu \mathrm{g})$ was then added together with $50 \mu \mathrm{l}$ of washed protein $\mathrm{A}$-agarose beads, and the tube was then rotated at $4^{\circ} \mathrm{C}$ for $3 \mathrm{hr}$. The beads were then spun down and washed three times with NET buffer. After the final wash, the beads were resuspended in $30 \mu$ l of Laemmli sample buffer, boiled for $5 \mathrm{~min}$, and then spun for $15 \mathrm{~min}$. The supernatant was loaded onto a $12.5 \%$ SDS-polyacrylamide gel. After electrophoresis, the gel was transferred to nitrocellulose, and immunoblotting was performed using a phospho-c-Jun monoclonal antibody (diluted $1: 1000$ ) that had been raised against the same phosphopeptide as that used for preparing the polyclonal antibody and that has a similar specificity (Lallemand, unpublished observations).

In vitro transcription and translation. c-Jun protein was produced in vitro using a TnT rabbit reticulocyte lysate or wheat germ extract system (Promega UK Ltd., Southampton, UK), according to the manufacturer's instructions. The plasmid pCDc-Jun (Ham et al., 1995) was used as template and contains the full-length mouse c-Jun open reading frame with a Kozak consensus initiation codon cloned downstream of the $\beta$-globin RNA leader sequence and bacteriophage T7 promoter. The $\beta$-globin leader has been shown to increase the efficiency of translation in vitro (Norman et al., 1988).

Immunofluorescence. Immunofluorescence experiments were performed with cells plated on glass coverslips. Cells were fixed in $3 \%$ paraformaldehyde for $30 \mathrm{~min}$ at room temperature, permeabilized with $0.5 \%$ Triton X-100, and then were blocked using $50 \%$ goat serum in $1 \%$ BSA in PBS. Primary and secondary antibodies were diluted in $10 \%$ goat serum in $1 \%$ BSA in PBS.

The polyclonal phospho-c-Jun antibody was used at a dilution of 1:250 for $16 \mathrm{hr}$ at $4^{\circ} \mathrm{C}$. FLAG $\Delta 169$ was detected with the M2 monoclonal antibody (IBI Kodak, Cambridge, UK) diluted 1:200. Bcl-2 was detected with a monoclonal antibody (clone 124) diluted 1:50 (Dako, Glostrup, Denmark). $\beta$-Galactosidase was detected using a rabbit polyclonal antibody (5 Prime $\rightarrow 3$ Prime, Inc., Boulder, CO) diluted 1:500. c-Jun ${ }^{\text {asp }}$ and c-Jun ${ }^{\text {ala }}$ were detected with a hemagglutinin (HA) monoclonal antibody (clone 12CA5, Boehringer Mannheim) diluted 1:2000. Fluorescein- or rhodamine-conjugated goat anti-mouse and goat anti-rabbit secondary antibodies (Jackson ImmunoResearch, West Grove, PA) were used at a dilution of 1:100. After incubation with the primary and secondary antibodies, nuclei were stained with Hoechst dye (H33342) at $1 \mu \mathrm{g} / \mathrm{ml}$. Coverslips were mounted in Citifluor (Citifluor, Canterbury, UK). Slides were viewed on a Nikon Microphot FXA fluorescence microscope. Color photographs were taken on Ektachrome 400x slide film (Kodak).

Northern analysis. Total RNA was prepared by the acid guanidinium thiocyanate phenol-chloroform method as described by Chomczynski and Saachi (1987). Twenty-microgram aliquots of total RNA were electrophoresed on $1.2 \%$ agarose gels containing formaldehyde, transferred to Hibond $\mathrm{N}^{+}$membranes (Amersham), and hybridized with ${ }^{32} \mathrm{P}$-labeled probes according to standard protocols (Sambrook et al., 1989). Membranes were stripped and reprobed with GAPDH to ensure equal loading between lanes. The probes used to detect the c-jun and GAPDH mRNAs were prepared from plasmids containing the mouse c-jun and rat GAPDH cDNAs, which were obtained from Moshe Yaniv (Institut Pasteur, Paris, France). The relative level of c-jun RNA was determined by scanning autoradiographs on an imaging densitometer (Bio-Rad).

Plasmids and transfection. Construction of pCDFLAG 169 and pCDBcl-2 was described previously (Ham et al., 1995). Cytomegalovirus (CMV) expression vectors for HA epitope-tagged c-Jun, c-Jun asp, and c-Jun ${ }^{\text {ala }}$ were provided by Dirk Bohmann (EMBL, Heidelberg, Germany), and CMVlacZ was provided by Art Alberts (ICRF, London, UK).

For transfection experiments, all plasmids were purified by centrifugation on two $\mathrm{CsCl}$ gradients. Transient transfection of granule neurons was performed by the calcium phosphate coprecipitation method (Graham and van der Eb, 1973) using a ProFection kit (Promega) according to the manufacturer's instructions. Briefly, neurons were cultured for $4 \mathrm{~d}$ in vitro on glass coverslips in 24-well dishes. pcDNA1, pCDFLAG $\Delta 169$, pCDBcl-2, wild-type c-Jun, c-Jun ${ }^{\text {asp, }}$, or c-Jun ${ }^{\text {ala }}$ were added to the transfection mix at a final concentration of $5 \mu \mathrm{g} / \mathrm{ml}$ together with $1 \mu \mathrm{g} / \mathrm{ml}$ of an expression vector encoding $\beta$-galactosidase (CMVlacZ) to allow detection of the transfected cells. Calcium phosphate-DNA precipitates were prepared by standard procedures and were allowed to form at room temperature for $30 \mathrm{~min}$. Fifty microliters of precipitate were added to the cells in $450 \mu \mathrm{l}$ of the original conditioned medium. After $8 \mathrm{hr}$, the cells were subjected to a $15 \%$ DMSO shock for $90 \mathrm{sec}$ at room temperature and then were washed three times with conditioned medium (from cells cultured for 4-7 d in vitro). The transfected cells were left for $36 \mathrm{hr}$ in conditioned medium to allow expression of plasmid DNA and also to ensure that the cells were fully dependent on potassium for survival. The medium was changed after the $36 \mathrm{hr}$, and the cells were fixed an additional $24 \mathrm{hr}$ later. The transfection efficiency was determined in immunofluorescence experiments by calculating the percentage of 
Hoechst-stained cells that expressed $\beta$-galactosidase and was typically 3-7\%. Furthermore, immunofluorescence analysis was performed to confirm that $\beta$-galactosidase was co-expressed with c-Jun, FLAG $\Delta 169$, or $\mathrm{Bcl}-2$, and that the proteins were localized correctly within neurons after transfection.

To analyze the effect of expression vectors on neuronal survival, the transfected cells were fixed and stained with an antibody against $\beta$-galactosidase and with Hoechst dye to visualize nuclear morphology. The viability of the transfected cells was calculated by scoring the percentage of $\beta$-galactosidase-expressing cells that had normal (nonpyknotic) nuclei. Coverslips were scored blind.

In vitro kinase assays. The cells were solubilized with lysis buffer (20 mM HEPES, pH 7.4, 2 mm EGTA, 1\% Triton X-100, 10\% glycerol, 1 mm DTT, $1 \mathrm{~mm}$ sodium orthovanadate, $50 \mathrm{~mm} \beta$-glycerophosphate, $1 \mathrm{~mm}$ PMSF, $1 \mu \mathrm{g} / \mathrm{ml}$ pepstatin A, $2 \mu \mathrm{g} / \mathrm{ml}$ aprotinin, and $10 \mu \mathrm{g} / \mathrm{ml}$ leupeptin) for $15 \mathrm{~min}$ on ice and then centrifuged at $13,000 \times g$ for $15 \mathrm{~min}$ at $4^{\circ} \mathrm{C}$. For immunoprecipitations, 50 or $100 \mu \mathrm{g}$ of cell extract was precleared with $50 \mu \mathrm{l}$ of protein A-agarose (Boehringer Mannheim), diluted 1:1 in lysis buffer, for $1 \mathrm{hr}$ at $4^{\circ} \mathrm{C}$. Endogenous JNK, p38, or MAP kinase was immunoprecipitated with specific polyclonal antibodies and $50 \mu \mathrm{l}$ of protein A-agarose for $2-3 \mathrm{hr}$ at $4^{\circ} \mathrm{C}$. One to $2 \mu \mathrm{l}$ of anti-JNK (SAPK) antiserum (Kyriakis et al., 1994), $2 \mu \mathrm{l}$ of anti-p38 (Xenopus Mpk2) antibody (Rouse et al., 1994), and $1 \mu \mathrm{g}$ of anti-MAP kinase (MAPK) antibody (rat MAPK R2; Erk1-CT from Upstate Biotechnology, Lake Placid, NY) was used for 50-100 $\mu \mathrm{g}$ of cell extract. The immunoprecipitates were washed three times with lysis buffer, two or three times with wash buffer I (100 mm Tris-HCl, pH 7.6, $500 \mathrm{~mm} \mathrm{LiCL}_{2}, 0.1 \%$ Triton $\mathrm{X}-100$, and $1 \mathrm{~mm}$ DTT), and two or three times with wash buffer II (25 mM HEPES, pH 7.5, 0.2\% Triton X-100, and 1 mM EDTA) before they were suspended in $30 \mu \mathrm{l}$ of kinase buffer (in mM: 25 HEPES, pH 7.5, 20 $\mathrm{MgCl}_{2}, 20 \beta$-glycerophosphate, $20 \quad p$-nitrophenylphosphate, 0.1 orthovanadate, and 2 DTT). MAPK and p38 immune complexes were washed once or twice with kinase buffer before the assay. The kinase reaction was started by the addition of $5 \mu \mathrm{Ci}$ of $\left[\gamma^{-32} \mathrm{P}\right]$ ATP $(>5000$ $\mathrm{Ci} / \mathrm{mmol})$, cold ATP to a final concentration of $20 \mu \mathrm{M}$, and 2-3 $\mu \mathrm{g}$ of glutathione $S$-transferase (GST)-cJun[1-169] (A. Eilers, unpublished observations), $2 \mu \mathrm{g}$ of GST-activating transcription factor 2 (ATF2) [1-96] (Santa Cruz Biotechnology, Santa Cruz, CA), or $10 \mu \mathrm{g}$ of myelin basic protein (Sigma) as substrate, respectively. After incubation for 15-30 min at $30^{\circ} \mathrm{C}$, the reaction was terminated by the addition of Laemmli sample buffer. The phosphorylation of the substrate proteins was examined after SDS-PAGE by autoradiography.

\section{RESULTS}

\section{Transcriptional commitment point}

The death of cerebellar granule neurons after $\mathrm{KCl}$ and serum deprivation can be delayed significantly when actinomycin D is included in the medium at concentrations that inhibit transcription (D’Mello et al., 1993; Galli et al., 1995; Schulz et al., 1996; Armstrong et al., 1997) (A. Watson, unpublished observations). As a first step toward understanding the transcriptional regulation of cell death in this system, we determined the transcriptional commitment point, defined as the time after removal of survival signals (serum and $25 \mathrm{~mm} \mathrm{KCl}$ ) at which only $50 \%$ of the neurons kept in $5 \mathrm{~mm} \mathrm{KCl}$ can be rescued by the addition of actinomycin D. A previous report suggested that the transcriptional commitment point was relatively early in cerebellar granule neurons (Galli et al., 1995). To confirm that this was the case in our cell culture system and to determine the transcriptional commitment point more precisely, we performed a detailed analysis at early time points after the removal of survival signals (Fig. 1). Granule neurons were switched to serum-free medium containing $5 \mathrm{~mm}$ $\mathrm{KCl}$, and actinomycin $\mathrm{D}$ or additional $\mathrm{KCl}$ was added to $1 \mu \mathrm{g} / \mathrm{ml}$ and $25 \mathrm{~mm}$, respectively, at different times after the medium had been changed. Survival was then assessed in an MTT assay $48 \mathrm{hr}$ after the initial reduction in $\mathrm{KCl}$ concentration. As can been seen in Figure 1, $50 \%$ of the neurons could not be rescued by the inhibition of RNA synthesis after $3 \mathrm{hr}$ in $5 \mathrm{~mm} \mathrm{KCl}$, suggesting that in these cells a gene or set of genes encoding proteins that

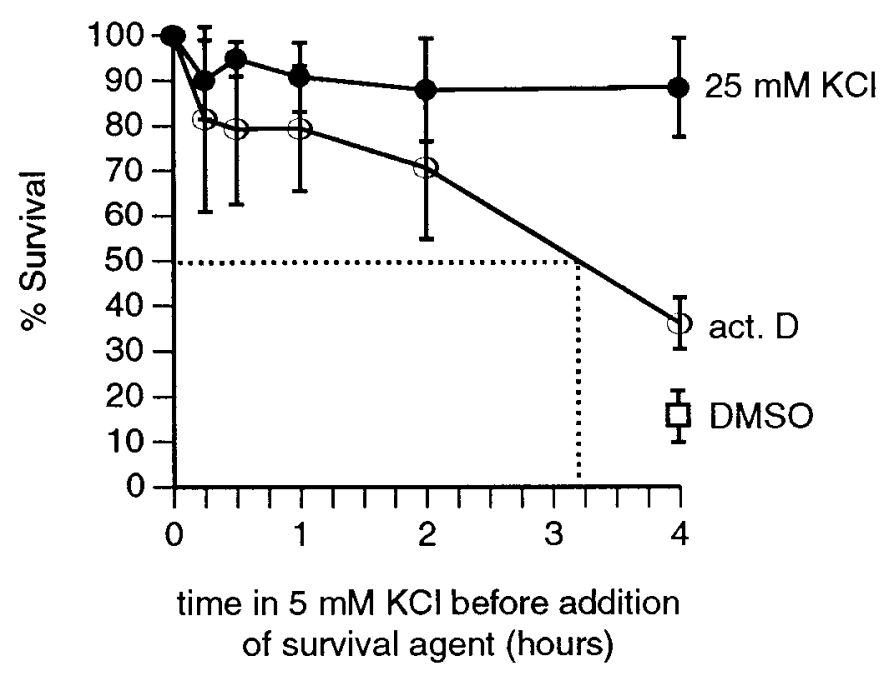

Figure 1. Determination of the transcriptional commitment point for cerebellar granule neurons undergoing apoptosis after withdrawal of survival signals. Cerebellar granule neurons plated in 96-well cell culture dishes were rinsed three times with serum-free BME containing $5 \mathrm{~mm}$ $\mathrm{KCl}$ and then were left in the same medium. At different times after reduction of the extracellular $\mathrm{KCl}$ concentration, actinomycin $\mathrm{D}$ (act. D; open circles) or additional $\mathrm{KCl}$ ( filled circles) was added to final concentrations of $1 \mu \mathrm{g} / \mathrm{ml}$ or $25 \mathrm{~mm}$, respectively. As a control, the vehicle for actinomycin D, DMSO, was added to $0.1 \%$ (open square). Survival was assessed $48 \mathrm{hr}$ later in an MTT assay. 100 corresponds to the MTT value after $48 \mathrm{hr}$ for the $25 \mathrm{~mm} \mathrm{KCl} 0 \mathrm{hr}$ time point. The results shown represent the average of five independent experiments $\pm \mathrm{SE}$.

trigger the cell death program had been transcribed by this time. In contrast, the addition of $\mathrm{KCl}$ to $25 \mathrm{~mm}$ could rescue $90 \%$ of the cells as late as $4 \mathrm{hr}$ after the initial reduction in $\mathrm{KCl}$ concentration, because the $\mathrm{KCl}$ commitment point was later than $4 \mathrm{hr}(\sim 12$ hr; data not shown).

\section{c-Jun is selectively induced before the transcriptional commitment point}

In experiments with NGF-dependent sympathetic neurons it has been established that c-jun RNA and protein levels increase after NGF withdrawal and that the activity of c-Jun is necessary for apoptosis (Estus et al., 1994; Ham et al., 1995). To determine whether this was also true in cerebellar granule neurons, we investigated which members of the Jun and Fos family were expressed and whether their pattern of expression changed on induction of apoptosis. To do this we performed immunoblotting experiments using affinity-purified polyclonal antibodies raised against the mouse Jun and Fos proteins (Lallemand et al., 1997). Cerebellar granule neurons were refed with serum-free medium containing 5 or $25 \mathrm{~mm} \mathrm{KCl}$. Whole-cell extracts were prepared at various times after the medium had been changed, and immunoblots were performed. Like sympathetic neurons, granule neurons expressed c-Jun, Jun B, and Jun D but not c-Fos or Fos B (Fig. $2 A$ ) (data not shown). When the cells were switched into medium containing $5 \mathrm{~mm} \mathrm{KCl}$, the level of c-Jun protein increased between 2 and $4 \mathrm{hr}$ after the medium had been changed, but there was no change in cells maintained in $25 \mathrm{~mm} \mathrm{KCl}$, indicating that the increase was specifically attributable to the decrease in $\mathrm{KCl}$ concentration rather than the removal of serum. Increased levels of c-Jun protein were observed at 4 and $8 \mathrm{hr}$, but by $24 \mathrm{hr}$ the amount of c-Jun had decreased to the same level as that in cells that had been kept in $25 \mathrm{~mm} \mathrm{KCl}$ (Fig. $2 B$ ). In contrast, the levels of Jun B and Jun D did not increase when the cells were cultured 
c-Jun

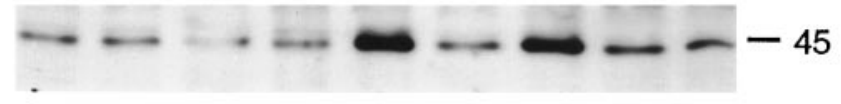

Jun B

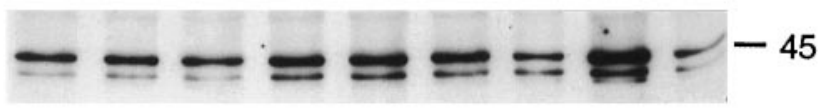

Jun D

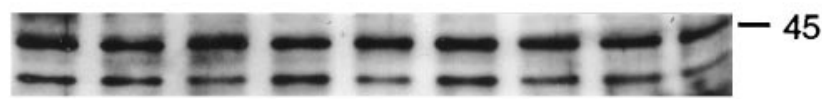

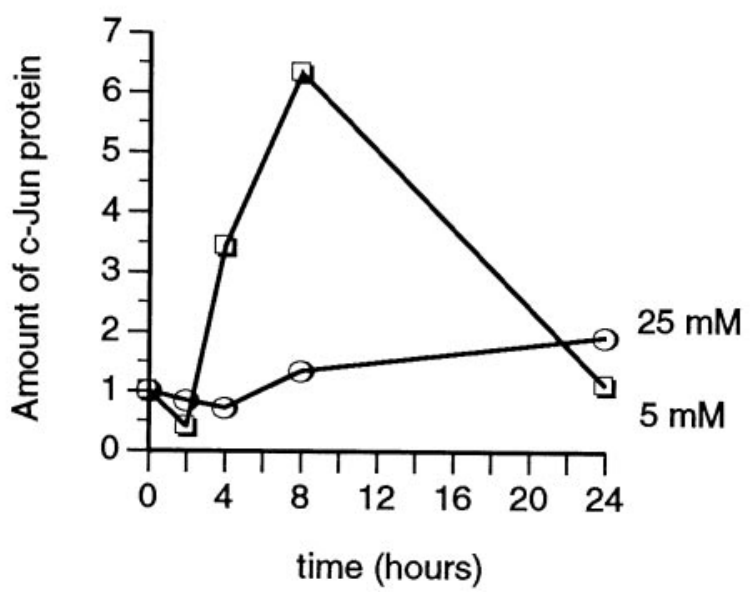

Figure 2. Pattern of expression of c-Jun, Jun B, and Jun D in cerebellar granule neurons deprived of survival signals. $A$, Cerebellar granule neurons were rinsed three times with serum-free $\mathrm{BME}$ supplemented with $5 \mathrm{mM} \mathrm{KCl}$ and were either maintained in the same medium or were refed with serum-free BME containing $25 \mathrm{~mm} \mathrm{KCl}$. At the times indicated, the cells were harvested, and whole-cell extracts were prepared. Proteins were separated on $12.5 \%$ SDS polyacrylamide gels, and immunoblotting was performed using affinity-purified polyclonal antibodies specific for c-Jun, Jun B, and Jun $\mathrm{D}$ (Lallemand et al., 1997). The positions and sizes in kilodaltons of molecular weight markers $(M W)$ that were run in parallel are shown on the right. c-Fos and Fos B were not detected in granule neuron extracts, although the c-Fos and Fos B antibodies recognized in vitro-translated c-Fos and Fos B in immunoblotting experiments (data not shown). $B$, The c-Jun immunoblot shown in $A$ was scanned on a densitometer, and the relative amount of c-Jun protein present in extracts from cells cultured in $25 \mathrm{mM} \mathrm{KCl}$ (open circles) or $5 \mathrm{~mm} \mathrm{KCl}$ (open squares) was plotted against time.

in $5 \mathrm{~mm} \mathrm{KCl}$ medium. There was, however, some increase in the level of Jun B protein in cells cultured in $25 \mathrm{mM} \mathrm{KCl}$, which might be a response to the removal of serum or to the addition of fresh medium. Finally, c-Fos and Fos B were still not detected after survival signal withdrawal (data not shown). Therefore, c-Jun was the only one of the AP-1 proteins examined that was affected significantly by reducing the $\mathrm{KCl}$ concentration, and the increase in c-Jun level started between 2 and $4 \mathrm{hr}$ after the removal of survival signals.

To determine whether the increase in the level of c-Jun protein was preceded by an increase in the amount of c-jun mRNA, we performed northern blotting experiments with RNA isolated from granule neurons. Two c-jun mRNAs with sizes of 2.7 and 3.4 $\mathrm{kb}$ were detected (Fig. $3 A$ ). These have been detected previously in fibroblasts and PC12 cells and are thought to differ in their $3^{\prime}$ ends (Ryseck et al., 1988; Bartel et al., 1989). Lowering the KCl concentration caused an increase in the level of c-jun mRNA within $1 \mathrm{hr}$, which reached a peak at $2 \mathrm{hr}$ and then started to decline (Fig. $3 A, B$ ). The c-jun mRNA was therefore induced before the transcriptional commitment point $(3 \mathrm{hr})$, and this induction was specific for cells in $5 \mathrm{mM} \mathrm{KCl}$ and was not accompanied by any change in GAPDH mRNA (Fig. $3 A$ ).

\section{AP-1 activity is required for cell death in cerebellar granule neurons}

We showed previously that microinjection of sympathetic neurons with an expression vector for a c-Jun dominant negative mutant (pCDFLAG $\Delta 169$ ) that lacks the transactivation domain and that can suppress AP-1 activity delayed cell death after NGF withdrawal (Ham et al., 1995). To determine whether interfering with c-Jun function would also inhibit apoptosis in granule neurons, we tested the effect of expressing FLAG $\Delta 169$ in these cells. As a means of introducing expression vectors into cerebellar granule neurons, we developed a method for transiently transfecting them based on calcium phosphate co-precipitation. pCDFLAG $\Delta 169$ was transfected into granule neurons together with a $\beta$-galactosidase expression vector, CMVlacZ. The transfected cells could therefore be detected by staining with an anti- $\beta$ galactosidase antibody. As a positive control we used a Bcl-2 expression vector, because overexpression of $\mathrm{Bcl}-2$ has been shown to slow the death of a number of neuronal types deprived of survival signals (Garcia et al., 1992; Allsopp et al., 1993). As a negative control we used the empty CMV expression vector pcDNA1. Figure $4 A$ shows representative granule neurons transfected with CMVlacZ and pCDFLAG $\Delta 169$ or pCDBcl-2, which were fixed and stained with a $\beta$-galactosidase antibody and antibodies against the FLAG epitope or Bcl-2, respectively. Both proteins were correctly localized; FLAG $\Delta 169$ was found in the nucleus, and Bcl-2 was found in the cell body.

To determine whether expression of FLAG $\Delta 169$ or Bcl- 2 could protect granule neurons against cell death induced by survival signal withdrawal, cells that had been cultured for $4 \mathrm{~d}$ in vitro were transfected with the appropriate expression vectors. Thirty-six hours after transfection, the cells were refed with serum-free medium containing $5 \mathrm{~mm} \mathrm{KCl}$. Twenty-four hours later, the cells were fixed, and neuronal viability was determined as follows; transfected cells were identified by staining with anti- $\beta$ galactosidase antibody, and nuclear morphology was visualized by Hoechst staining. Cells with condensed, pyknotic nuclei, shrunken cell bodies, and fragmented neurites were scored as apoptotic. Figure $4 B$ shows cells that were transfected with CMVlacZ and pcDNA1 or pCDFLAG $\Delta 169$ and that were cultured in serum-free medium containing $5 \mathrm{~mm} \mathrm{KCl}$ before being fixed and 
A

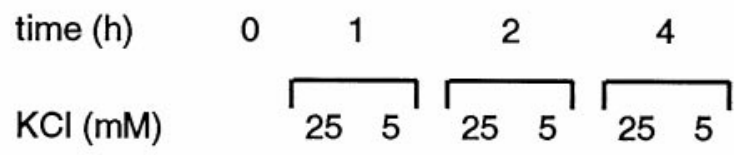

c-jun

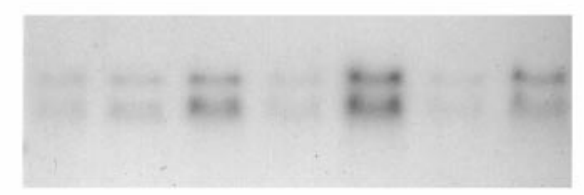

GAPDH

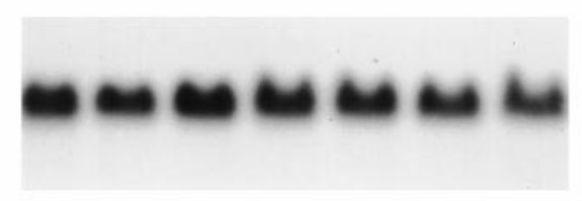

B

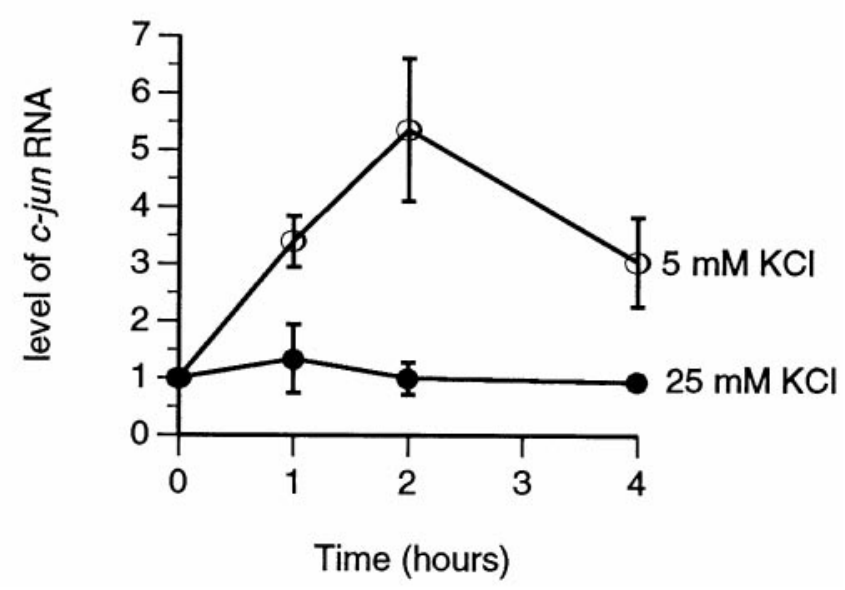

Figure 3. The c-jun RNA increases in level before the transcriptional commitment point. $A$, Cerebellar granule neurons were switched into serum-free BME containing either 25 or $5 \mathrm{mM} \mathrm{KCl}$, and total RNA was isolated at the times indicated. The RNA samples were electrophoresed on a $1.2 \%$ agarose gel containing formaldehyde and then were transferred to a Hibond $\mathrm{N}^{+}$membrane. The filter was hybridized with a ${ }^{32} \mathrm{P}$-labeled c-jun probe. After autoradiography, the filter was stripped and rehybridized with a GAPDH probe. $B$, c-jun RNA levels were determined by scanning autoradiographs on a densitometer, and the relative level of c-jun RNA in either $25 \mathrm{mM} \mathrm{KCl}$ (filled circles) or $5 \mathrm{mM} \mathrm{KCl}$ (open circles) was plotted against time. The data shown represent the average of two independent Northern hybridization experiments $\pm \mathrm{SE}$.

stained. Examples of normal (Fig. $4 B, N$ ) and apoptotic (Fig. 4B, $A)$ transfected cells are marked with arrows. After $24 \mathrm{hr}$ in $5 \mathrm{~mm}$ $\mathrm{KCl}$ only $18 \%$ of the neurons transfected with pcDNA1 displayed the characteristics of normal cells, with round cell bodies and normal nuclei (Fig. $4 C$ ). In contrast, $93 \%$ of the cells transfected with pCDBcl-2 and $73 \%$ of the cells transfected with pCDFLAG $\Delta 169$ were viable. Furthermore, expression of FLAG $\Delta 169$ or Bcl-2 had no adverse effect on neuronal viability in medium containing $25 \mathrm{~mm} \mathrm{KCl} \mathrm{(Fig.} 4 C$ ). These results demonstrate that AP-1 activity is necessary for cell death in granule neurons, because expression of a c-Jun dominant negative mutant, which inhibits AP-1 activity (Ham et al., 1995), prevented cell death. Furthermore, because c-Jun was the only member of the AP-1 family that increased in level after survival signal withdrawal, and because this occurred before the transcriptional commitment point, it seems likely that c-Jun plays an important role in the death of these neurons.

\section{C-Jun is phosphorylated on serine $\mathbf{6 3}$ during apoptosis}

The activity of the c-Jun protein is regulated by phosphorylation at specific sites (Karin, 1995). In particular, serines 63 and 73 in the transactivation domain play a key role. Phosphorylation of these residues increases the ability of c-Jun to activate the transcription of target genes (Pulverer et al., 1991; Smeal et al., 1991). To determine whether c-Jun was phosphorylated on serine 63 after survival signal withdrawal, we made use of a phospho-c-Junspecific antibody that only recognizes c-Jun when it is phosphorylated at serine 63 and that does not recognize unphosphorylated c-Jun or phosphorylated Jun B or Jun D (D. Lallemand, unpublished observations). The specificity of this antibody is demonstrated in Figure $5 A$. When translated in a rabbit reticulocyte lysate, c-Jun becomes phosphorylated on serines 63 and 73 and threonines 91 and 93 and runs as a ladder of bands (Pulverer et al., 1991). In contrast, c-Jun protein synthesized in a wheat germ extract system is not phosphorylated and runs as a single band. In immunoblotting experiments with these in vitro-translated proteins, a normal c-Jun antibody raised against amino acids 1-58 of c-Jun (Lallemand et al., 1997) recognized both forms of c-Jun, whereas the phospho-c-Jun antibody only detected phosphorylated c-Jun (Fig. 5A, c-Jun RRL).

We then used the phospho-c-Jun antibody in immunofluorescence experiments with cerebellar granule neurons (Fig. 5B). Control cultures that had been maintained in $25 \mathrm{~mm} \mathrm{KCl}$ in the absence of serum showed little, if any, staining with the phosphoc-Jun antibody (data not shown). This was also the case immediately after the cells had been switched into serum-free medium containing $5 \mathrm{~mm} \mathrm{KCl}$ (Fig. $5 B, O h$ ), whereas $1 \mathrm{hr}$ after $\mathrm{KCl}$ and serum deprivation, phosphorylated c-Jun localized to the nucleus was readily detected (Fig. $5 B$ ). This staining pattern was not observed when the phospho-c-Jun antibody was incubated with the phosphopeptide that had been used to make the antibody but was unaffected by the addition of the equivalent nonphosphorylated peptide (data not shown). Thus, in granule neurons deprived of survival signals, specific nuclear phospho-c-Jun staining appeared before c-Jun protein levels had increased significantly (Fig. 2). The intensity of the staining had increased further at 4 $\mathrm{hr}$, paralleling the increase in c-Jun protein detected by immunoblotting. As judged by Hoechst staining, the phosphorylation of c-Jun on serine 63 occurred before any of the nuclear changes characteristic of apoptotic cells.

The immunofluorescence results with the phospho-c-Jun antibody were confirmed by performing a sequential immunoprecipitation and immunoblotting experiment using extracts from granule neurons and polyclonal and monoclonal phospho-c-Jun antibodies (Fig. 5C). In pilot experiments we found that to obtain a satisfactory signal in immunoblots with cell extracts, it was necessary to enrich for phospho-c-Jun by first immunoprecipitating with a polyclonal phospho-c-Jun antibody before performing immunoblotting with a monoclonal phospho-c-Jun antibody. This may be because the phospho-c-Jun antibody recognizes its epitope more efficiently when the c-Jun protein is not denatured. As a control, we used extracts from unstimulated and UVirradiated Rat1 cells. As expected, the phospho-c-Jun monoclo- 
A

\section{pCDFLAG $\Delta 169$}

pCDBcl-2

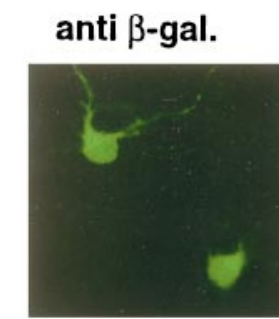

M2 / anti-Bcl-2

B anti $\beta$-gal.
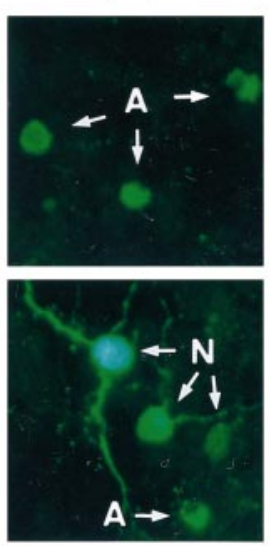

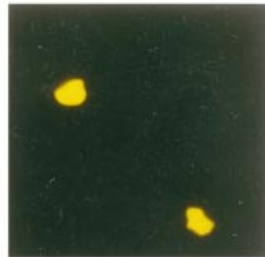

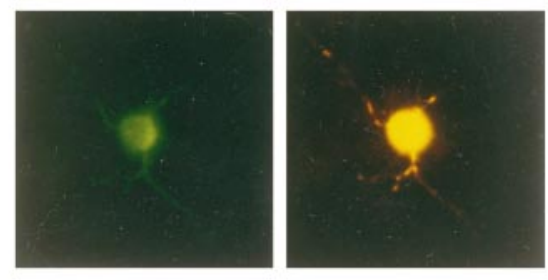

pCDFLAG 169

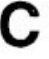

$5 \mathrm{mM} \mathrm{KCl}$

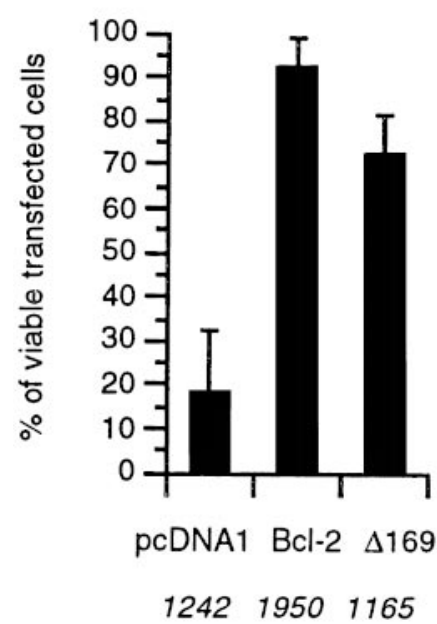

$25 \mathrm{mM} \mathrm{KCl}$

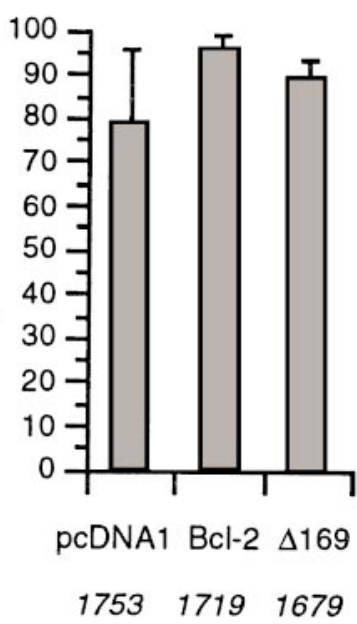

Figure 4. Overexpression of Bcl-2 or the c-Jun dominant negative mutant FLAG $\Delta 169$ protects cerebellar granule neurons against cell death induced by survival signal withdrawal. $A$, Cerebellar granule neurons cultured on glass coverslips were transfected with pCDFLAG 169 or $\mathrm{pCDBcl}-2$ together with the $\beta$-galactosidase expression vector CMVlacZ, as described in Materials and Methods. The cells were subsequently fixed

nal antibody recognized bands that corresponded in size to phosphorylated forms of c-Jun in immunoprecipitates of extracts from UV-treated but not unstimulated cells. A higher molecular weight band that probably corresponds to immunoglobulin was also detected. This band was not seen if the polyclonal phospho-c-Jun antibody was not added during the immunoprecipitation step (Fig. 5C, no $a b$ ). Consistent with our immunofluorescence results, bands corresponding to phospho-c-Jun were detected, as early as $1 \mathrm{hr}$ after changing the medium, in extracts from granule neurons cultured in serum-free medium containing $5 \mathrm{mM} \mathrm{KCl}$ but not in extracts from cells cultured in $25 \mathrm{mM} \mathrm{KCl}$ medium (Fig. 5C).

\section{Phosphorylation of c-Jun is necessary for cell death}

To determine whether phosphorylation of the c-Jun transactivation domain was necessary for the induction of apoptosis in granule neurons, cells were transfected with expression vectors for either wild-type c-Jun or c-Jun ${ }^{\text {asp}, ~ a ~ c o n s t i t u t i v e l y ~ a c t i v e ~}$ mutant in which the known and potential serine and threonine phosphorylation sites in the activation domain have been mutated to aspartic acid, or c-Jun ${ }^{\text {ala }}$, an inactive protein that cannot be activated by phosphorylation, because the same residues have been mutated to alanine (Fig. 6A) (Papavassiliou et al., 1995). HA epitope-tagged c-Jun, c-Jun ${ }^{\text {asp }}$, and c-Jun ${ }^{\text {ala }}$ were expressed efficiently in transfected cells, as determined by immunofluorescence with an anti-HA antibody (data not shown). In the presence of $10 \%$ serum and $25 \mathrm{~mm} \mathrm{KCl}$, overexpression of wild-type c-Jun or c-Jun ${ }^{\text {ala }}$ had little effect on cell viability, whereas the majority $(80 \%)$ of the cells transfected with c-Jun ${ }^{\text {asp }}$ had pyknotic nuclei. When serum was removed, expression of wild-type c-Jun induced apoptosis in $65 \%$ of the transfected cells, whereas the alanine mutant and pcDNA1 did not cause a significant increase in the percentage of apoptotic cells (Fig. 6B). Thus overexpression of wild-type c-Jun alone was sufficient in itself to induce apoptosis under certain conditions ( $25 \mathrm{~mm} \mathrm{KCl}$, no serum). In contrast, expression of the constitutively active c-Jun ${ }^{\text {asp }}$ induced apoptosis efficiently under all conditions, whereas c-Jun ala, which cannot be phosphorylated, was unable to induce cell death under any of the conditions tested. Thus the ability of the various forms of c-Jun to induce apoptosis in granule neurons correlated with their potential phosphorylation status.

Previous work by Treier et al. (1995) and Peverali et al. (1996) showed that a Drosophila Jun ${ }^{\text {ala }}$ mutant could act as a dominant

\footnotetext{
$\leftarrow$

and stained with an antibody against $\beta$-galactosidase to identify the transfected cells and with the FLAG-specific M2 antibody or an anti-Bcl-2 antibody. FLAG $\Delta 169$ localized to the nucleus, as judged by comparison with Hoechst staining (results not shown). Bcl-2 localized to the cell body and neurites. $B$, Morphology of normal and apoptotic cerebellar granule neurons. Cells were transfected with CMVlacZ and pcDNA1 or pCDFLAG $\Delta 169$. Thirty-six hours after transfection the cells were switched into $5 \mathrm{~mm} \mathrm{KCl} \mathrm{medium.} \mathrm{After} \mathrm{fixation,} \mathrm{the} \mathrm{transfected} \mathrm{cells} \mathrm{were} \mathrm{identi-}$ fied by staining with an anti- $\beta$-galactosidase antibody, and nuclear morphology was visualized by Hoechst staining. Apoptotic $(A)$ and normal $(N)$ cells are marked by white arrows. Apoptotic cells have a highly condensed, brightly staining nucleus. $C$, Cerebellar granule neurons were transfected with CMVlacZ plus pcDNA1 or pCDBcl-2 or pCDFLAG $\Delta 169$. Thirty-six hours after transfection, the cells were refed with serum-free medium containing either 5 or $25 \mathrm{~mm} \mathrm{KCl}$. Twenty-four hours later the cells were fixed and stained with an anti- $\beta$-galactosidase antibody and Hoechst dye. The percentage of transfected cells that were viable, i.e., had a normal morphology, was then determined. The results shown are the average of nine independent experiments \pm SE. For each construct the total number of transfected cells that were scored is indicated. The coverslips were counted in a blinded manner.
} 
A

C-Jun Ab.

phospho-c-Jun Ab.

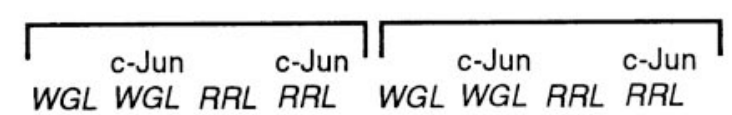

c-Jun [

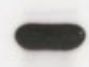

2

B

phospho-c-Jun

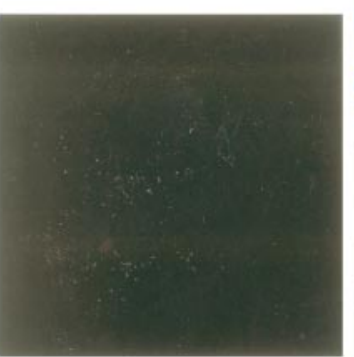

$1 \mathrm{~h}$

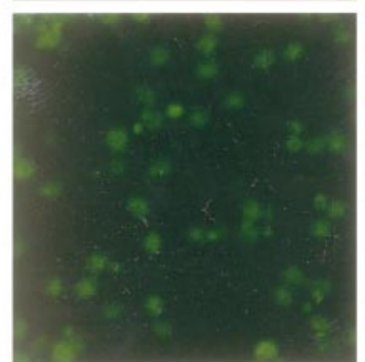

$4 \mathrm{~h}$
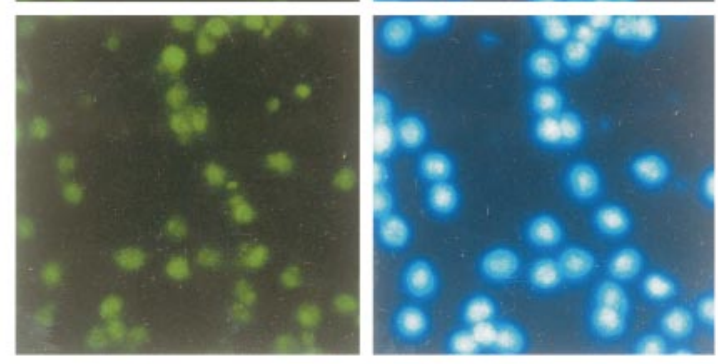

C
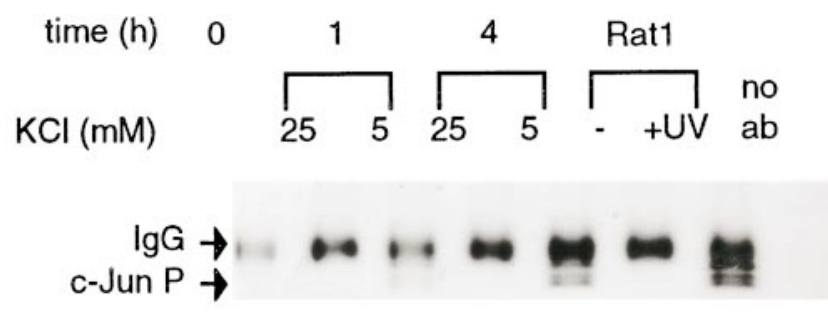

Figure 5. c-Jun becomes phosphorylated on serine 63 soon after cerebellar granule neurons are deprived of survival signals. $A$, c-Jun protein was synthesized in a wheat germ lysate transcription-translation system (c-Jun WGL) or a rabbit reticulocyte lysate (c-Jun $R R L$ ). c-Jun translated in the wheat germ lysate is not phosphorylated and runs as a single band, whereas c-Jun translated in the rabbit reticulocyte system is phosphorylated at serines 63 and 73 and threonines 91 and 93 and runs as a ladder of bands with a lower mobility in SDS polyacrylamide gels. The in inhibitor of R7 photoreceptor differentiation. To determine whether c-Jun ${ }^{\text {ala }}$ could block apoptosis in granule neurons, cells were transfected with c-Jun ${ }^{\text {ala }}$ and then were induced to die by removing serum and lowering the extracellular $\mathrm{KCl}$ concentration. After $24 \mathrm{hr}$ in $5 \mathrm{~mm} \mathrm{KCl}$, only a minority of the cells transfected with pcDNA1, wild-type c-Jun or c-Jun ${ }^{\text {asp }}$ were viable $(10 \%$ in this series of experiments). In contrast, $50 \%$ of the cells transfected with c-Jun ala were viable (Fig. $6 B$ ). c-Jun ${ }^{\text {ala }}$ appeared to block cell death less efficiently than the c-Jun deletion mutant FLAG $\Delta 169$ (compare Figs. $4 C, 6 B$ ). This may be because c-Jun ${ }^{\text {ala }}$ can still activate transcription weakly (Metivier et al., 1993), whereas FLAG $\Delta 169$ cannot. In conclusion, these results indicate that expression of c-Jun, in particular the activated form c-Jun ${ }^{\text {asp }}$, is sufficient in itself to induce apoptosis in cerebellar granule neurons cultured in the presence of survival signals. Furthermore, it appears that phosphorylation of c-Jun is necessary for apoptosis induced by survival signal withdrawal, because overexpression of c-Jun ${ }^{\text {ala }}$, which cannot be phosphorylated, delays cell death.

\section{Cerebellar granule neurons contain a high level of Jun kinase activity, which does not increase after survival signal withdrawal}

Members of the MAPK superfamily are known to regulate the activity of the c-jun promoter and c-Jun protein (Karin, 1995). Jun kinases (JNK/SAPKs) bind directly to c-Jun with high affinity and phosphorylate serines 63 and 73, thereby increasing the transcriptional activity of the c-Jun protein (Pulverer et al., 1991; Smeal et al., 1991; Dérijard et al., 1994; Kyriakis et al., 1994). Jun kinases can also increase the rate of transcription of the c-jun gene, because c-Jun binds as a heterodimer with ATF-2 to TRElike sites in the c-jun promoter, and the transactivation domains of both proteins are phosphorylated by Jun kinase (Van Dam et al., 1993, 1995; Herr et al., 1994). Three JNK genes have been identified, which through alternative splicing give rise to multiple isoforms (Kyriakis et al., 1994; Gupta et al., 1996). p38 kinase, which can also be activated by stress, does not phosphorylate the

$\leftarrow$

vitro-translated proteins and corresponding unprogrammed lysates (WGL and $R R L$ ) were electrophoresed on a $10 \%$ SDS polyacrylamide gel. After transfer to nitrocellulose, immunoblots were performed with a c-Jun antibody that was raised against amino acids 1-58 of c-Jun (c-Jun Ab.) diluted 1:400 or with the polyclonal phospho-c-Jun-specific antibody diluted 1:2000. $B$, Cerebellar granule neurons cultured on glass coverslips were rinsed with serum-free $\mathrm{BME}$ containing $5 \mathrm{mM} \mathrm{KCl}$ and then were maintained in the same medium. At the time points indicated, the cells were fixed and stained with a phospho-c-Jun-specific antibody and Hoechst dye. Nuclear phospho-c-Jun staining was clearly visible $1 \mathrm{hr}$ after survival signal withdrawal and had increased in intensity at $4 \mathrm{hr}$. The specificity of the staining pattern was confirmed by peptide competition (data not shown). Furthermore, granule neurons cultured in BME plus $10 \%$ FCS plus $25 \mathrm{~mm} \mathrm{KCl}$ did not stain with the phospho-c-Jun antibody (data not shown). $C$, Cerebellar granule neurons were rinsed with serumfree $\mathrm{BME}$ containing $5 \mathrm{mM} \mathrm{KCl}$ and then were maintained in the same medium or in medium supplemented with $25 \mathrm{~mm} \mathrm{KCl}$. At the time points indicated, extracts were prepared, and phospho-c-Jun was immunoprecipitated using a polyclonal phospho-c-Jun antibody, as described in Materials and Methods. The resulting immunoprecipitates were electrophoresed on a $12.5 \%$ SDS-polyacrylamide gel and transferred to nitrocellulose, and immunoblots were performed using a monoclonal phosphoc-Jun antibody. The position of phosphorylated c-Jun (c-Jun P) and of a nonspecific band that probably corresponds to $\mathrm{IgG}$ is indicated. Extracts from untreated and UV-irradiated Rat1 cells were used as controls. Antibody was also ommitted from a duplicate Rat1 $(+U V)$ immunoprecipitation as a further control (no $a b$ ). 
A

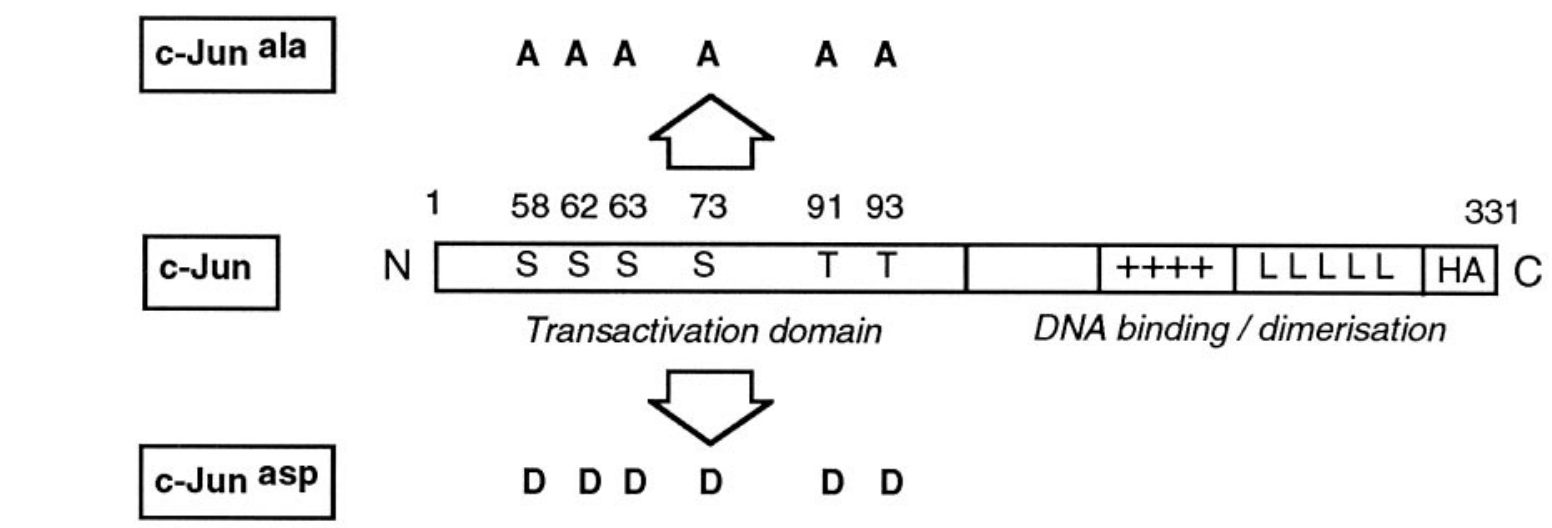

B

$25 \mathrm{mM} \mathrm{KCl}+10 \%$ serum

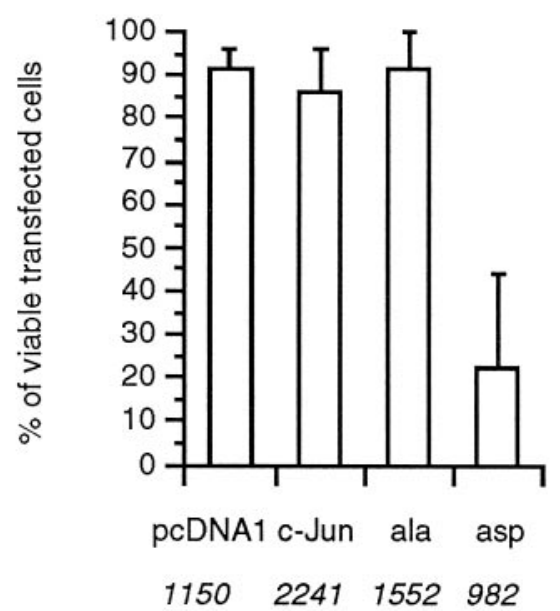

$25 \mathrm{mM} \mathrm{KCl}$

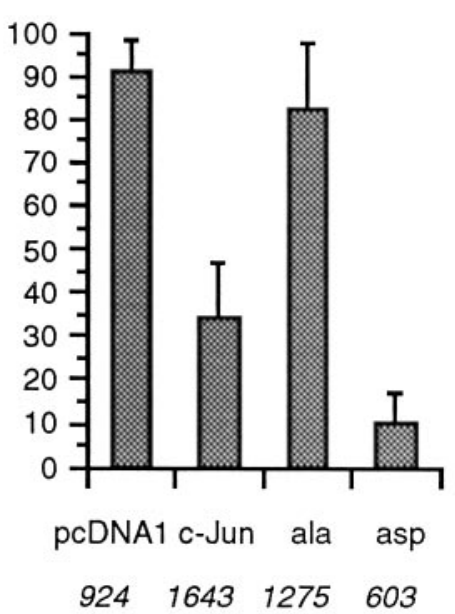

$5 \mathrm{mM} \mathrm{KCl}$

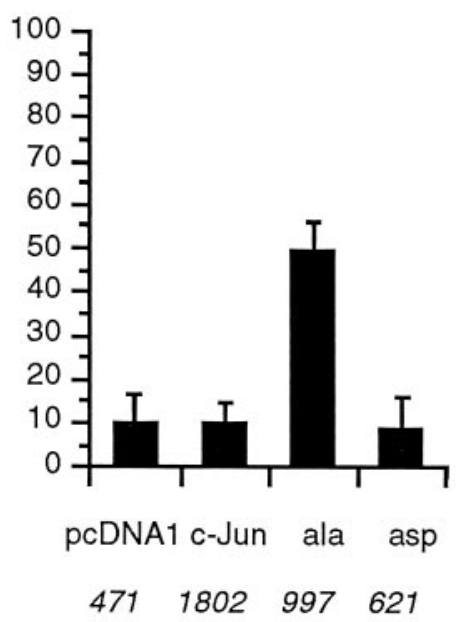

Figure 6. Phosphorylation of c-Jun is necessary for the induction of apoptosis in cerebellar granule neurons. $A$, Structure of c-Jun and the N-terminal

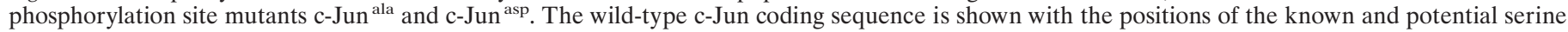
and threonine phosphorylation sites in the transactivation domain marked. All of these residues were mutated to either alanine $(A)$ or aspartic acid $(D)$ in c-Jun ${ }^{\text {ala }}$ and c-Jun ${ }^{\text {asp }}$, respectively (Papavassiliou et al., 1995). The position of the basic/leucine zipper DNA binding/dimerization domain is also indicated, together with a C-terminal HA epitope tag. $B$, Cerebellar granule neurons were transfected with the constructs shown together with CMVlacZ. Thirty-six hours after transfection, the cells were rinsed and refed with BME medium containing $25 \mathrm{~mm} \mathrm{KCl} \mathrm{plus} 10 \%$ serum or only 25 or $5 \mathrm{~mm} \mathrm{KCl}$. Twenty-four hours later, the cells were fixed and stained with an anti- $\beta$-galactosidase antibody and Hoechst dye, and the percentage of viable transfected cells was determined. The results shown are the average of four independent experiments \pm SE. The total number of transfected cells scored for each transfection mix is indicated. The coverslips were counted blind.

c-Jun protein in vitro but can activate the $c$-jun promoter, because it phosphorylates ATF-2 (Raingeaud et al., 1995, 1996). Furthermore, JNK/SAPKs and p38 kinase are activated in NGFdeprived PC12 cells undergoing apoptosis, and the p38 pathway is important for PC12 cell death (Xia et al., 1995). Finally, although the MAP kinases ERK-1 and ERK-2 can phosphorylate c-Jun in vitro (Pulverer et al., 1991), there is no evidence that they do so in vivo in mammalian cells. However, there are certain agents, such as $12-O$-tetradecanoylphorbol-13-acetate, that activate MAP kinase but not Jun kinase and that also activate the $c$-jun promoter (Cano et al., 1995). To determine whether the activity of any of these kinases increased in parallel with the increases in c-jun RNA, protein, and phosphorylation levels that occurred after $\mathrm{KCl}$ deprivation, we performed immune complex kinase assays with extracts from granule neurons.

To immunoprecipitate Jun kinases we used an antibody raised 
A

Figure 7. Measurement of Jun kinase, p38 kinase, and MAP kinase activity in extracts from cerebellar granule neurons deprived of survival signals. Cerebellar granule neurons were rinsed three times and then were maintained in serum-free BME containing either 25 or $5 \mathrm{~mm} \mathrm{KCl}$. At the times indicated, extracts for kinase assays were prepared as described in Materials and Methods. $A$, Jun kinases were immunoprecipitated from cell extracts using a pan-SAPK antibody that recognizes all of the different rat Jun kinase isoforms (Kyriakis et al., 1994). After washing of the immunoprecipitates, the activity of the kinases was assayed using GST-cJun[1-169] as substrate. As a control, extracts from quiescent $(-)$ or UV-treated $(U V) \mathrm{HeLa}$ cells were assayed in parallel. $B$, p38 kinase was immunoprecipitated from cell extracts using a Xenopus mpk2/p38 antibody, which also recognizes mammalian p38 (Rouse et al., 1994). After the immunoprecipitates had been washed, p38 kinase activity was assayed using GST-ATF-2[196] as substrate. Control extracts were prepared from undifferentiated PC12 cells, which had been pretreated with anisomycin at $10 \mu \mathrm{g} / \mathrm{ml}$ for $30 \mathrm{~min}(A)$ or irradiated with short-wavelength $(254 \mathrm{~nm}) \mathrm{UV}$ light $(U V)$. $C$, MAP kinases were immunoprecipitated from cell extracts using an antibody that recognizes multiple ERK isoforms (rat MAPK R2; Erk1-CT from Upstate Biotechnology). MAP kinase activity was assayed using myelin basic protein $(M B P)$ as substrate.

time (h)
$\mathrm{KCl}(\mathrm{mM})$
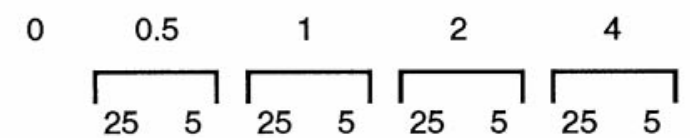

Hela

$\mathrm{KCl}(\mathrm{mM})$
GST c-Jun
$\mathrm{KCl}(\mathrm{mM})$
$\mathrm{GST}$ ATF-2
time (h)
$\mathrm{KCl}(\mathrm{mM})$
$\mathrm{MBP}$

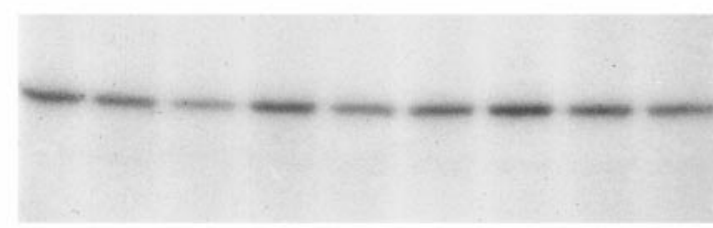

- UV
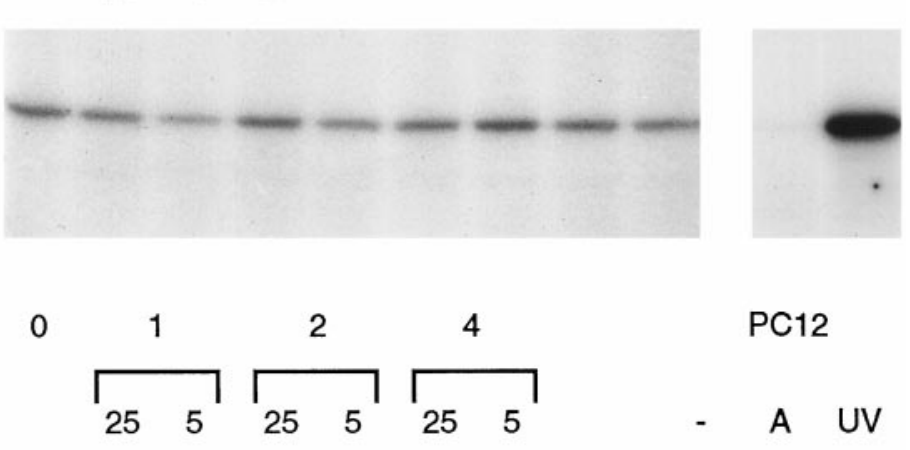

$\mathrm{PC} 12$
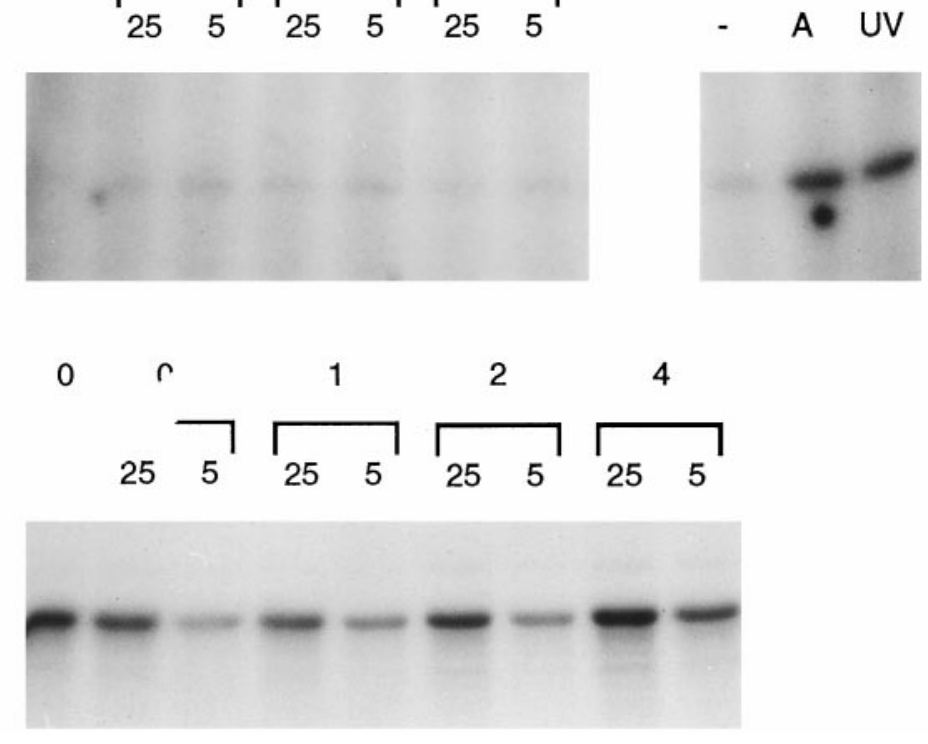

with anisomycin or UV radiation, and we found that this was the case when we tested extracts from PC12 cells that had been treated in this way (Fig. 7B). Like unstimulated PC12 cells, cerebellar granule neurons only had low levels of p38 kinase activity. However, this did not increase when the cells were refed with serum-free medium containing $5 \mathrm{~mm} \mathrm{KCl}$. Finally, we performed MAP kinase assays using a pan-MAPK antibody, which recognizes several members of the MAPK family, and myelin basic protein as the substrate. We found that granule neurons contained readily detectable levels of MAPK activity, which decreased after survival signal withdrawal (Fig. 7C). In conclusion, none of the kinases examined was activated when granule neurons were refed with low $\mathrm{KCl}$ medium. Rather, the cells appeared to contain very high constitutive levels of JNK activity and low levels of p38 activity, neither of which increased when the extracellular $\mathrm{KCl}$ concentration was reduced. In contrast, MAP kinase activity decreased after survival signal withdrawal.

\section{DISCUSSION}

In the case of several different types of primary neuron, cell death induced by survival signal withdrawal can be delayed dramatically by the addition of actinomycin $\mathrm{D}$ at concentrations that will inhibit transcription. This has suggested the hypothesis that the withdrawal of survival signals leads to the transcriptional induction of genes that encode proteins that promote cell death. Are immunoprecipitated kinase we used GST-ATF-2[1-96] as substrate. p38 kinase activity can be induced strongly by treating cells neurons (data not shown).

To immunoprecipitate p38 kinase we used an antibody prepared against the Xenopus mpk2/p38, which also recognizes mammalian p38 (Rouse et al., 1994). To measure the activity of the 
similar genes activated in different kinds of neurons after survival signal withdrawal? We and others previously have studied the pattern of expression of members of the AP-1 family in sympathetic neurons undergoing apoptosis and found that c-jun RNA and protein levels increased selectively after NGF withdrawal (Estus et al., 1994; Ham et al., 1995). c-jun RNA levels also increased in differentiated PC12 cells deprived of NGF (Mesner et al., 1995) and in cerebellar granule neurons after $\mathrm{KCl}$ and serum deprivation (Miller and Johnson, 1996). Here we have demonstrated that in cerebellar granule neurons the c-jun RNA is induced rapidly after survival signal withdrawal, peaking at $2 \mathrm{hr}$, before the transcriptional commitment point ( $3 \mathrm{hr}$; Fig. 1), and that the level of c-Jun protein increases. Furthermore, we showed that AP-1 activity was necessary for cell death, because expression of FLAG $\Delta 169$, a c-Jun dominant negative mutant that inhibits AP-1 activity, increased the percentage of viable cells after survival signal withdrawal. Expression of FLAG $\Delta 169$ also protected sympathetic neurons or PC12 cells against NGF withdrawal-induced death (Ham et al., 1995; Xia et al., 1995). In c-jun -/- knockout mice, programmed cell death occurs normally in dorsal root ganglion (DRG) neurons at least up to embryonic day 11.5 (Roffler-Tarlov et al., 1996). However, because these mice die during midgestation, it has not been possible to use them to study apoptosis in postnatal sympathetic neurons or cerebellar granule neurons. It is possible that the death of embryonic DRG neurons may not be affected in these animals, because other members of the AP-1 family or other transcription factors, such as ATF-2, can substitute for c-Jun. Alternatively, the signal transduction pathways that activate programmed cell death in embryonic DRG neurons may be different from those functioning in postnatal sympathetic and cerebellar granule neurons.

The transcriptional activity of the c-Jun protein is increased by phosphorylation of serines 63 and 73 in the transactivation domain. Using a phospho-c-Jun-specific antibody we showed that in granule neurons c-Jun was phosphorylated on serine 63 soon after the extracellular $\mathrm{KCl}$ concentration had been lowered, suggesting that c-Jun activity increases during apoptosis. To determine whether phosphorylation of c-Jun was important for cell death in granule neurons, we investigated the effect of overexpressing different c-Jun mutants in which the phosphorylation sites had been altered. A constitutively active mutant in which the serine and threonine phosphoacceptor sites in the transactivation domain had been mutated to aspartic acid was able to induce apoptosis when expressed in granule neurons cultured in medium containing $10 \%$ serum and $25 \mathrm{mM} \mathrm{KCl}$, whereas the wild-type c-Jun protein could not. On the other hand, when wild-type c-Jun was overexpressed in cells cultured in serum-free medium containing $25 \mathrm{~mm} \mathrm{KCl}$, it was able to induce cell death. This result suggests that serum may contain a factor that prevents wild-type c-Jun from killing granule neurons. c-Jun ${ }^{\text {ala }}$, an inactive c-Jun mutant, which cannot be phosphorylated, did not induce apoptosis under any conditions. However, expression of c-Jun ${ }^{\text {ala }}$ protected granule neurons against apoptosis after survival signal withdrawal. Because the only difference between wild-type c-Jun and c-Jun $^{\text {ala }}$ is that the latter lacks the phosphoacceptor sites, this result suggests that phosphorylation of c-Jun is necessary for cell death in granule neurons. c-Jun ${ }^{\text {ala }}$ has a reduced ability to activate transcription (Smeal et al., 1991), and c-Jun ${ }^{\text {ala }}$ isolated from mammalian cells is unable to bind to a probe containing a TRE site in electrophoretic mobility shift assays (Papavassiliou et al., 1995). Overexpressed c-Jun ${ }^{\text {ala }}$ may act as a dominant negative mutant by sequestering kinases, such as the JNK/SAPKs, that normally would directly bind to and activate the endogenous c-Jun protein. Alternatively, c-Jun ${ }^{\text {ala }}$ might interact with coactivator proteins that potentiate transactivation by c-Jun, such as CBP or JAB1 (Arias et al., 1994; Claret et al., 1996). c-Jun ${ }^{\text {ala }}$ appeared to inhibit apoptosis less efficiently than the c-Jun deletion mutant FLAG $\Delta 169$ (compare Figs. 4, 6), which may be because it is expressed less efficiently or because it is still partially active (Metivier et al., 1993). Jun mutants similar to those described here have previously been used to show that Drosophila Jun (D-Jun) plays an important role in photoreceptor differentiation in the developing compound eye (Bohmann et al., 1994; Treier et al., 1995; Peverali et al., 1996). A D-Jun ${ }^{\text {asp }}$ mutant could induce R7 photoreceptor differentiation, whereas D-Jun ${ }^{\text {ala }}$ acted as a dominant negative mutant (Treier et al., 1995; Peverali et al., 1996).

Because we had obtained evidence that c-Jun phosphorylation is important for cell death in granule neurons, we investigated whether there were changes in the activity of any of the members of the MAP kinase superfamily that are known to regulate c-jun gene expression and c-Jun phosphorylation. We found that extracts from granule neurons contained high levels of Jun kinase activity, low levels of p38 kinase activity, and high levels of MAP kinase activity. After survival signal withdrawal, there was no increase in the level of Jun kinase or p38 kinase activity, whereas MAP kinase activity decreased. These results are different to those obtained for differentiated PC12 cells, in which both Jun kinase and p38 kinase were activated after NGF withdrawal (Xia et al., 1995) (Eilers, unpublished observations), and suggest that in cerebellar granule neurons novel mechanisms may exist for regulating c-Jun levels and c-Jun phosphorylation. One possibility is that granule neurons may contain a Jun kinase isoform that is not recognized by the pan-SAPK antibody that we used for immune complex kinase assays. Alternatively, given that granule neurons contain very high basal levels of Jun kinase activity, it is possible that in the presence of survival signals there are phosphatase activities that prevent the c-Jun transactivation domain from remaining phosphorylated. After survival signal withdrawal, the level of phosphatase activity might decrease, thereby allowing c-Jun phosphorylated by JNK/SAPKs to accumulate. Because MAP kinase activity declines in granule neurons after survival signal withdrawal, another possibility is that it is the balance between the level of MAP kinase and Jun kinase activity that influences cell survival, as has been reported for differentiated PC12 cells deprived of NGF (Xia et al., 1995).

An alternative explanation for our results is that perhaps, in addition to Jun kinase, cerebellar granule neurons may contain a novel kinase that is activated by lowering the extracellular $\mathrm{KCl}$ concentration and that stimulates the c-jun promoter or phosphorylates c-Jun. In the developing Drosophila eye, in which Jun phosphorylation is important for photoreceptor differentiation, D-Jun was a substrate for the ERK-related MAP kinase Rolled, which is part of the signal transduction pathway that triggers R7 photoreceptor differentiation (Peverali et al., 1996). Furthermore, although Drosophila Jun kinase (D-JNK) can phosphorylate D-Jun in vitro, fly ommatidia that lack D-JNK can develop normally (Riesgo-Escovar et al., 1996).

The transcriptional activation function of c-Jun and its partners seems to be important for apoptosis in cerebellar granule neurons, because the two c-Jun mutants that blocked cell death in these cells are both unable to activate transcription; FLAG $\Delta 169$ lacks the transactivation domain, and c-Jun ${ }^{\text {ala }}$ only activates transcription weakly. The c-Jun target genes that are important for 
neuronal cell death have yet to be identified. One may be the c-jun gene itself, because c-Jun is known to be able to activate transcription of the c-jun promoter (Angel et al., 1988). Cerebellar granule neurons appear to contain adequate levels of the effectors of apoptosis, because they can be killed by high concentrations of the broad-spectrum kinase inhibitor staurosporine in the presence of inhibitors of protein synthesis (Taylor et al., 1997). Therefore, after survival signal withdrawal, c-Jun may not activate the expression of genes encoding apoptosis effector proteins but, rather, may induce genes that code for molecules that activate the effectors of cell death. The identification of c-Jun target genes that are important for cell death will help resolve the apparent paradox that, as well as playing a role in neuronal cell death, c-Jun is also implicated in cell proliferation and neuronal regeneration. Furthermore, if c-Jun proves to be important for cell death in vivo, an understanding of c-Jun regulation and the mechanism by which c-Jun induces cell death may lead to the development of novel strategies for treating diseases of the nervous system in which neuronal apoptosis occurs.

\section{REFERENCES}

Allsopp TE, Wyatt S, Paterson HF, Davies AM (1993) The protooncogene $b c l-2$ can selectively rescue neurotrophic factor-dependent neurons from apoptosis. Cell 73:295-307.

Angel P, Hattori K, Smeal T, Karin M (1988) The jun proto-oncogene is positively autoregulated by its product, Jun/AP1. Cell 55:875-885.

Arias J, Alberts AS, Brindle P, Claret FX, Smeal T, Karin M, Feramisco J, Montminy M (1994) Activation of cAMP and mitogen responsive genes relies on a common nuclear factor. Nature 370:226-229.

Armstrong RC, Aja TJ, Hoang KD, Gaur S, Bai X, Alnemri ES, Litwack G, Karanewsky DS, Fritz LC, Tomaselli KJ (1997) Activation of the CED3/ICE-related protease cpp32 in cerebellar granule neurons undergoing apoptosis but not necrosis. J Neurosci 17:553-562.

Barde Y-A (1989) Trophic factors and neuronal survival. Neuron 2:1525-1534.

Bartel DP, Sheng M, Lau LF, Greenberg ME (1989) Growth factors and membrane depolarization activate distinct programs of early response gene expression: dissociation of fos and jun induction. Genes Dev 3:304-313.

Bohmann D, Ellis MC, Staszewski LM, Mlodzik M (1994) Drosophila Jun mediates Ras-dependent photoreceptor determination. Cell 78:973-986.

Cano E, Hazzalin CA, Kardalinou E, Buckle RS, Mahadevan LC (1995) Neither ERK nor JNK/SAPK MAP kinase subtypes are essential for histone H3/HMG-14 phosphorylation or $c$-fos and c-jun induction. J Cell Sci 108:3599-3609.

Chomczynski P, Sacchi N (1987) Single-step method of RNA isolation by acid guanidinium thiocyanate-phenol-chloroform extraction. Anal Biochem 162:156-159.

Claret F-X, Hibi M, Dhut S, Toda T, Karin M (1996) A new group of conserved coactivators that increase the specificity of AP-1 transcription factors. Nature 383:453-457.

Dérijard B, Hibi M, Wu I-H, Barrett T, Su B, Deng T, Karin M, Davis RJ (1994) JN K1: a protein kinase stimulated by UV light and Ha-Ras that binds and phosphorylates the c-Jun activation domain. Cell 78:1025-1037.

D’Mello SR, Galli C, Ciotti T, Calissano P (1993) Induction of apoptosis in cerebellar granule neurons by low potassium: inhibition of death by insulin-like growth factor I and cAMP. Proc Natl Acad Sci USA 90:10989-10993.

Estus S, Zaks WJ, Freeman RS, Gruda M, Bravo R, Johnson EM (1994) Altered gene expression in neurons during programmed cell death: identification of c-jun as necessary for neuronal apoptosis. J Cell Biol 127:1717-1727.

Galli C, Meucci O, Scorziello A, Werge TM, Calissano P, Schettini G (1995) Apoptosis in cerebellar granule cells is blocked by high $\mathrm{KCl}$, forskolin and IGF-1 through distinct mechanisms of action: the involvement of intracellular calcium and RNA synthesis. J. Neurosci 15:1172-1179.

Gao W-Q, Heintz N, Hatten ME (1991) Cerebellar granule cell neurogenesis is regulated by cell-cell interactions in vitro. Neuron 6:705-715.
Garcia I, Martinou I, Tsujimoto Y, Martinou J-C (1992) Prevention of programmed cell death of sympathetic neurons by the bcl-2 protooncogene. Science 258:302-304.

Graham FL, Van der Eb AJ (1973) A new technique for the assay of infectivity of human adenovirus 5 DNA. Virology 52:456.

Gupta S, Barrett T, Whitmarsh AJ, Cavanagh J, Sluss HK, Dérijard B, Davis RJ (1996) Selective interaction of JNK protein kinase isoforms with transcription factors. EMBO J 15:2760-2770.

Ham J, Babij C, Whitfield J, Pfarr CM, Lallemand D, Yaniv M, Rubin LL (1995) A c-Jun dominant negative mutant protects sympathetic neurons against programmed cell death. Neuron 14:927-939.

Hatten ME (1985) Neuronal regulation of astroglial morphology and proliferation in vitro. J Cell Biol 100:384-396.

Herr I, van Dam H, Angel P (1994) Binding of promoter-associated AP-1 is not altered during induction and subsequent repression of the c-jun promoter by TPA and UV irradiation. Carcinogenesis 15:1105-1113.

Hibi M, Lin A, Smeal T, Minden A, Karin M (1993) Identification of an oncoprotein and UV-responsive protein kinase that binds and potentiates the c-Jun activation domain. Genes Dev 7:2135-2148.

Johnson EM, Deckwerth TL (1993) Molecular mechanisms of developmental neuronal death. Annu Rev Neurosci 16:31-46.

Karin M (1995) The regulation of AP-1 activity by mitogen-activated protein kinases. J Biol Chem 270:16483-16486.

Kyriakis JM, Banerjee P, Nikolakaki E, Dai T, Rubie EA, Ahmad MF, Avruch J, Woodgett JR (1994) The stress-activated protein kinase subfamily of c-Jun kinases. Nature 369:156-160.

Lallemand D, Spyrou G, Yaniv M, Pfarr CM (1997) Variations in Jun and Fos protein expression and AP-1 activity in cycling, resting and stimulated fibroblasts. Oncogene 14:819-830.

Martin DP, Schmidt RE, DiStefano PS, Lowry OH, Carter JG, Johnson EM (1988) Inhibitors of protein synthesis and RNA synthesis prevent neuronal death caused by nerve growth factor deprivation. J Cell Biol 106:829-844.

Mesner PW, Epting CL, Hegarty JL, Green SH (1995) A timetable of events during programmed cell death induced by trophic factor withdrawal from neuronal PC12 cells. J Neurosci 15:7357-7366.

Metivier C, Piu F, Pfarr CM, Yaniv M, Loiseau L, Castellazzi M (1993) In vitro transforming capacities of mouse c-jun: jun D chimeric genes. Oncogene 8:2311-2315.

Miller TM, Johnson EM (1996) Metabolic and genetic analyses of apoptosis in potassium/serum-deprived rat cerebellar granule cells. J Neurosci 16:7487-7495.

Milligan CE, Oppenheim RW, Schwartz LM (1994) Motoneurons deprived of trophic support in vitro require new gene expression to undergo programmed cell death. J Neurobiol 25:1005-1016.

Mossman T (1983) Rapid colorimetric assay for cellular growth and survival: application to proliferation and cytotoxicity assays. J Immunol Methods 65:55-63.

Norman C, Runswick M, Pollock R, Treisman R (1988) Isolation and properties of cDNA clones encoding SRF, a transcription factor that binds to the c-fos serum response element. Cell 55:989-1003.

Oppenheim RW (1991) Cell death during development of the nervous system. Annu Rev Neorosci 14:453-501.

Papavassiliou AG, Treier M, Bohmann D (1995) Intramolecular signal transduction in c-Jun. EMBO J 14:2014-2019.

Peverali FA, Isaksson A, Papavassiliou AG, Plastina P, Staszewski LM, Mlodzik M, Bohmann D (1996) Phosphorylation of Drosophila Jun by the MAP kinase Rolled regulates photoreceptor differentiation. EMBO J 15:3943-3950.

Pulverer BJ, Kyriakis JM, Avruch J, Nikolakaki E, Woodgett JR (1991) Phosphorylation of c-jun mediated by MAP kinases. Nature 353:670-674.

Raingeaud J, Gupta S, Rogers JS, Dickens M, Han J, Ulevitch RJ, Davis RJ (1995) Pro-inflammatory cytokines and environmental stress cause p38 mitogen-activated protein kinase activation by dual phosphorylation on tyrosine and threonine. J Biol Chem 270:7420-7426.

Raingeaud J, Whitmarsh AJ, Barrett T, Dérijard B, Davis RJ (1996) MKK3- and MKK6-regulated gene expression is mediated by the p38 mitogen-activated protein kinase signal transduction pathway. Mol Cell Biol 16:1247-1255.

Riesgo-Escovar JR, Jenni M, Fritz A, Hafen E (1996) The Drosophila Jun-N-terminal kinase is required for cell morphogenesis but not for DJun-dependent cell fate specification in the eye. Genes Dev 10:2759-2768. 
Roffler-Tarlov S, Brown JJG, Tarlov E, Stolarov J, Chapman DL, Alexiou M, Papaioannou VE (1996) Programmed cell death in the absence of c-Fos and c-Jun. Development 122:1-9.

Rouse J, Cohen P, Trigon S, Morange M, Alonso-Llamazares A, Zamanillo D, Hunt T, Nebreda AR (1994) A novel kinase cascade triggered by stress and heat shock that stimulates MAPKAP kinase- 2 and phosphorylation of the small heat shock proteins. Cell 78:1027-1037.

Ryseck R-P, Hirai SI, Yaniv M, Bravo R (1988) Transcriptional activation of c-jun during the $\mathrm{G}_{0} / \mathrm{G}_{1}$ transition in mouse fibroblasts. Nature 334:535-537.

Sambrook J, Fritsch EF, Maniatis T (1989) Molecular cloning: a laboratory manual. Cold Spring Harbor, NY: Cold Spring Harbor Laboratory.

Schulz JB, Weller M, Klockgether T (1996) Potassium deprivationinduced apoptosis of cerebellar granule neurons: a sequential requirement for new mRNA and protein synthesis, ICE-like protease activity, and reactive oxygen species. J Neurosci 16:4696-4706.

Scott SA, Davies AM (1990) Inhibition of protein synthesis prevents cell death in sensory and parasympathetic neurons deprived of neurotrophic factor in vitro. J Neurobiol 21:630-638.
Smeal T, Binetruy B, Mercola DA, Birrer M, Karin M (1991) Oncogenic and transcriptional cooperation with Ha-Ras requires phosporylation of c-Jun on serines 63 and 73. Nature 354:494-496.

Taylor J, Gatchalian CL, Keen G, Rubin LL (1997) Apoptosis in cerebellar granule neurons: involvement of interleukin- $1 \beta$ converting enzyme-like proteases. J Neurochem 68:1598-1605.

Treier M, Bohmann D, Mlodzik M (1995) JUN cooperates with the ETS domain protein Pointed to induce photoreceptor R7 fate in the Drosophila eye. Cell 83:753-760.

Van Dam H, Duyndam M, Rottier R, Bosch A, de Vries-Smits L, Herrlich P, Zantema A, Angel P, van der Eb AJ (1993) Heterodimer formation of c-Jun and ATF-2 is responsible for induction of c-jun by the 243 amino acid adenovirus E1A protein. EMBO J 12:479-487.

Van Dam H, Wilhelm D, Herr I, Steffen A, Herrlich P, Angel P (1995) ATF-2 is preferentially activated by stress-activated protein kinases to mediate c-jun induction in response to genotoxic agents. EMBO J 14:1798-1811.

Xia Z, Dickens M, Raingeaud J, Davis RJ, Greenberg ME (1995) Opposing effects of ERK and JNK-p38 MAP kinases on apoptosis. Science 270:1326-1331. 